\begin{tabular}{c} 
International Journal of Biological Research, $4(2)(2016) 102-104$ \\
International Journal of Biological Research \\
WPC \\
Website: $\begin{array}{c}\text { www.sciencepubco.com/index.php/IJBR } \\
\text { doi: } 10.14419 / \text { ijbr.v4i2.6354 } \\
\text { Research paper }\end{array}$ \\
\hline
\end{tabular}

\title{
Composting process: a review
}

\author{
Shahid Raza *, Jalil Ahmad \\ Department of Biological sciences, University of South Asia, Lahore Pakistan \\ *Corresponding author E-mail: dr.raza03@gmail.com
}

\begin{abstract}
Composting is one of the important and economical method of recycling organic waste. Composting process involve a number of microbes. Composting have several benefits, it improves manure handling, possible saleable product, improves land application, weed seed and pathogen destruction by high temperature in compost pile, minimum risk of different pollution problems, perfect soil conditioner. Composting is a process in which biological breakdown of organic waste under different controlled conditions takes place.
\end{abstract}

Keywords: Composting, Lignoprotein, Parameters, Organic matter,Biofertilizer.

\section{Introduction}

Composting is a process converting the bio-chemical organic matter into humus (Lignoproteins) by the help of mesophilic and thermophilic organisms. A composting process seeks to connect the natural forces of decomposition to safe the conversion of organic waste into organic fertilizer. There are two main groups of organisms which decompose organic matter.

a. Anaerobic bacteria which perform their work in the absence of oxygen.

b. Aerobic bacteria which perform their work in the presence of oxygen.

Plant nutrients are very important for the development of crops and hygienic food for the increasing population of world. Plant nutrients are major and important component of sustainable agriculture (Ryckeboer et al., 2003). Bio fertilizer made by composting process has been identified as an alternative to chemical fertilizer to enhance soil fertility and crop production (Michael et al. 1995). There is large number of genetic heterogeneity in microbes. Studying the microbial variety in the environment is the inability to get many of microbes in culture (Sait et al., 2002).

The main characteristics of anaerobic composting are the process is a lengthy one extending over a period of 4 to 12 months. It is a low temperature process and the destruction of pathogens is not fully accomplished. The gaseous products of reduction like methane, hydrogen sulphide produce offensive odors. Nutrients are lost (Saet et al., 2001). Nutrients are lost. Aerobic composting is characterized by rapid decomposition normally completed within 8-10 weeks. During this period high temperatures are attained leading to speedy destruction of pathogens, insect eggs and weed seeds. These materials also produce an unpleasant smell during degradation (Golabi et al., 2003). Production of foul smelling gases like methane, hydrogen sulphide is minimized. Nutrients are fairly preserved. In order to accelerate and control the aerobic composting a specially formulated biological inoculum is used to treat the organic waste, which is the key element in aerobic composting. Time of composting process depends on $\mathrm{C}$ : $\mathrm{N}$, aeration, particle size, moisture content and temperature (Dees and Ghiorse, 2001).

\section{Factors affecting the composting process}

There are many important parameters that need to be check during the process of composting to get the good quality of compost and for early maturation. These parameters include porosity, temperature, oxygen, $\mathrm{C}$ : N, Moisture content, windrow weight, $\mathrm{pH}, \mathrm{EC}$ and CEC (Wakchaure et al., 2013)

The following factors affect the rate of successful composting.

Moisture content

Moisture content of the waste should be between 50-55\%. Lesser moisture will lead to mortality of microbes. Whereas more moisture will lead to anaerobic conditions making the inoculated microbes ineffective in the process of composting and emission of greenhouse gases with foul smell. The high amount of moisture content above than $75 \%$ is not beneficial for compost pile as it decreases the temperature of the pile by cooling it and decrease the production of microbial activity and biomass (Tiquia et al., 1996).

\section{Temperature}

Pace et al., (1995) reported that the composting of organic waste taking place between two temperature profiles, one is thermophilic and the second is mesophilic. The start of decomposition takes place in thermophilic environment. The exothermic biological activities of aerobic bacteria temperature rise to $65-70^{\circ} \mathrm{C}$ within a couple of days. This temperature has to be maintained throughout the biological cycle. Hassen et al., (2001) reported that the temperature of the compost windrow is thermophilic and it decreases as the bacterial count decreases in the windrow.

\section{Proper aeration}

Since aerobic bacteria are used in the biological process, proper aeration is required to ensure availability of oxygen is very important. Regular turning of the heaps will provide adequate aeration. . To provide the proper aeration, turning of windrows is important. (Ghao et al., 2010; Pace et al., 1995) reported that the 
large amount of oxygen should be provided at the start to initiate the aerobic composting

\section{Carbon \& nitrogen ratio $(\mathrm{CN}$ ratio)}

CN Ratio should be maintained below 50 for speedy composting If it is high, the decomposition process will be slow. If CN Ratio is very high, Nitrogenous material like cow-dung may have to be added to bring down CN Ratio to the desired level. At the end of biological process, CN Ratio should come down below 15. Kavitha and Sabramarian, (2007) reported that the optimum C: N at the start of composting process should be below 30:1 and at the end it should be decreased to $20: 1$.

\section{Importance of close monttoring}

Mechanical screening follows the biological process. The screening system will, be screening whatever is fed on the basis of size and specific gravity. The texture and quality of the end product as well as recovery percentage solely depend on competition and perfection of the biological process. Hence, it is very important to closely monitor the biological process, so as to have maximum output of desired quality. Screening system will not be able to correct and cover up omissions in the biological process to improve recovery process and quality. Hence biological process is the critical element in this technology, and has to be clearly understood, closely monitored and optimally controlled. Properly trained and fully devoted team should be engaged for windrow management. Success of the project wholly depends upon perfect windrow management.

Biological activity is a batch process. Hence micro level monitoring of each batch is very essential to find out abnormality if any and to take remedial action soon on observation. In this case each day's arrival is to be considered as a batch. Such batch should be given a code for reference. It would be better to use date and month to form the reference code for easy recognition. For example, the batch formed on 1St January may be christened as JAN-1. The most important format in this SOP is for keeping the case history of each hatch from date of arrival through biological cycle till first screening. (EIA, 2011) This format is annexed at ' $D$ '

The following factors are to be closely monitored:

Quality and quantity of incoming garbage

Treatment with inoculum

Windrow formation

Moisture level

Leachate formation

Temperature timely turning

Maturity house keeping

\section{Incoming garbage quality}

The composition of incoming garbage is very important. If organic fraction in the incoming garbage is less, naturally recovery of the end product will also be very less. Hence, quality of incoming garbage will have to be periodically inspected and monitored. Garbage coming from different sources will be different in composition. It should be ensured that garbage generated from vegetable markets, fish markets, fruit markets etc which is very rich in organic content should be brought to the project site regularly. Initial survey of the collection methods, routes of transportation, and location specific characteristics should be done and mapped. This data should be updated periodically every year. Composition of garbage at different localities could also be analyzed so that qualitative grading can be done for various collection points (EIA, 2011).

\section{Defining waste composition}

Collect a representative sample of garbage not less than $200 \mathrm{~kg}$ total in a sampling day about 10 kilograms from each randomly selected incoming truckloads and spread the sample on the floor. Sort the garbage manually into different component like wet vegetable and food waste, garden pruning, hard wooden material, dry leaves, fibrous material, paper, plastic, rubber, glass, metal, and other non-degradable items.

Weigh each component separately and calculate the percentage brake down.

Initially, the exercise should be done one selected day in every month for one year to obtain data for seasonality, and thereafter one sampling day in every Quarter (e.g. March, June, September, December) to confirm whether there is any change in the composition which was recorded earlier. Efforts should be made to locate such sources from where good quality garbage is receivable and such sources should be fully tapped (EIA, 2011).

\section{Carbon nitrogen ratio}

Another important factor to be seen is the $\mathrm{CN}$ ratio. If the incoming garbage contains more of dry leaves, straw, etc, heavy dose of cow dung or any Nitrogen rich organic waste will have to be applied to make the CN Ratio to the desired level. Otherwise, the biological cycle may take longer time than anticipated.

\section{0. pH value}

The $\mathrm{pH}$ value of the degradable fractions should also be ascertained. It should be in the range 6 to 8 ; otherwise biological activity will be considerably slowed down. If $\mathrm{pH}$ is more than 8 , it suggests that municipal authorities are using lime or bleaching powder at the collection/storage points. This practice should be discouraged as it detrimentally affects the biological process. They should be advised to use SANITREAT and or HERBOCEL instead, to control bad odor and flies.

\section{Corrective action}

If the organic content of a truckload incoming to dumping site is suspected to be low (say less than $40 \%$ ), that shipment should be rejected and sent direct to the MB dumping site. For improving the CN Ratio, cow dung or poultry manure etc can be added, depending upon availability and affordability. Quantity to be added will have to be worked out through trials at site. If quantity of leaves, wheat/paddy straw, etc are more and separable without much cost and effort, they should be separated and shredded and soaked in Cow dung slurry for at least 48 hours and thereafter mix with the rest of organic waste while forming windrows.

\section{Quantity of incoming garbage}

Proper assessment of quantity of incoming garbage is very important from two angles, to estimate adequate dosage of biological inoculums for treatment and to estimate and monitor overall recovery percentage of the end product.

\section{Conclusion}

Composting is the best way to recycle organic waste. There are different factors that affect the process of composting and it can be improved by optimizing parameters. The review of literature has revealed many aspects of making organic fertilizer by degrading organic waste with addition of microbial inoculums, to decrease the time duration of composting process as well as improving quality of mature compost various inoculums can be added. Many 
biological and chemical tests can be performed to check the maturity and stability of compost. The mature compost is safe for the plants. It is concluded from this study that the compost is a best soil conditioner; it improves the structure of soil and provide better nutrients to plants.

\section{References}

[1] Ryckeboer, J., Mergaert, J., Coosemans, J., Deprins, K., \& Swings, J. (2003). Microbiological aspects of biowaste during composting in a monitored compost bin. Journal of Applied Microbiology, 94 (1), 127-137. http://dx.doi.org/10.1046/j.1365-2672.2003.01800.x.

[2] Goyal, S., Dhull, S. K., \& Kapoor, K. K. (2005). Chemical and biological changes during composting of different organic wastes and assessment of compost maturity. Bioresource Technology, 96 (14), 1584-1591. http://dx.doi.org/10.1016/j.biortech.2004.12.012.

[3] Kanat, G., Demir, A., Ozkaya, B., \& Bilgili, M. S. (2006). Addressing the operational problems in a composting and recycling plant. Waste Management, $26 \quad$ (12), 1384-1391. http://dx.doi.org/10.1016/j.wasman.2005.12.010.

[4] Sánchez-Monedero, M. A., Roig, A., Paredes, C., \& Bernal, M. P. (2001). Nitrogen transformation during organic waste composting by the Rutgers system and its effects on $\mathrm{pH}, \mathrm{EC}$ and maturity of the composting mixtures.Bioresource Technology, 78 (3), 301-308. http://dx.doi.org/10.1016/S0960-8524(01)00031-1.

[5] Hassen, A., Belguith, K., Jedidi, N., Cherif, A., Cherif, M., and Boudabous, A. (2001). Microbial characterization during composting of municipal solid waste. Bioresource technology, 80 (3): 217 225. http://dx.doi.org/10.1016/S0960-8524(01)00065-7.

[6] Ryckeboer, J., Mergaert, J., Coosemans, J., Deprins, K., and Swings, J. 2003. Microbiological aspects of biowaste during composting in a monitored compost bin. Journal of Applied Microbiology, 94 (1): 127-137. http://dx.doi.org/10.1046/j.1365-2672.2003.01800.x.

[7] Michel Jr, F. C., Pecchia, J. A., Rigot, J., and Keener, H. M. 2003. Mass and nutrient losses during composting of dairy manure with sawdust versus straw amendment. Compost Science and Utilization, 23: 1-33.

[8] Dees, P. M., \& Ghiorse, W. C. (2001). Microbial diversity in hot synthetic compost as revealed by PCR-amplified rRNA sequences from cultivated isolates and extracted DNA. FEMS Microbiology Ecology, 35(2), 207-216. http://dx.doi.org/10.1111/j.15746941.2001.tb00805.x.

[9] Sait, M., Hugenholtz, P., \& Janssen, P. H. (2002). Cultivation of globally distributed soil bacteria from phylogenetic lineages previously only detected in cultivation-independent surveys. Environmental Microbiology, 4 (11), 654-666. http://dx.doi.org/10.1046/j.1462-2920.2002.00352.x.

[10] Gao, M., Liang, F., Yu, A., Li, B., and Yang, L. 2010. Evaluation of stability and maturity during forced-aeration composting of chicken manure and sawdust at different $\mathrm{C} / \mathrm{N}$ ratios. Chemosphere, 78 (5):614-619. http://dx.doi.org/10.1016/j.chemosphere.2009.10.056.

[11] Tiquia, S. M., and Tam, N. F. Y. 2000. Fate of nitrogen during composting of chicken litter. Environmental Pollution, 110 (3): 535-541. http://dx.doi.org/10.1016/S0269-7491(99)00319-X.

[12] Kavitha, R., and Subramanian, P. 2007. Bioactive compost-a value added compost with microbial inoculants and organic additives. Journal of Applied Science, 7 (17): 2514-2518. http://dx.doi.org/10.3923/jas.2007.2514.2518.

[13] Wakchaure, V. N., Zhou, J., Hoffmann, S., \& List, B. (2010). Catalytic Asymmetric Reductive Amination of $\alpha$-Branched Ketones. Angewandte Chemie, 122(27), 4716-4718. http://dx.doi.org/10.1002/ange.201001715.

[14] Golabi, S. M., Nourmohammadi, F., \& Saadnia, A. (2003). Electrosynthesis of organic compounds. Part II: Electrooxidative amination of 1, 4-dihydroxybenzene using some aliphatic amines. Journal of Electroanalytical Chemistry, 548, 41-47. http://dx.doi.org/10.1016/s0022-0728(03)00218-3.

[15] Environmental impact assessment of Lahore compost Pvt Ltd (2011). 